\title{
WSTĘP
}

Magdalena Karasek*

\section{NOWE WYMIARY GLOTTODYDAKTYKI: PROBLEMY NAUCZANIA STYLISTYCZNYCH I SPECJALISTYCZNYCH ODMIAN POLSZCZYZNY I INNYCH JĘZYKÓW ORAZ KSZTAŁCENIA DZIECI I MLODZIEŻY}

Słowa kluczowe: dydaktyka, nauczanie język polskiego jako obcego, odmiany specjalistyczne, badania, style, gatunki, glottodydaktyka polonistyczna

Streszczenie. W artykule przedstawione zostały główne tezy i koncepcje prac zamieszczonych w 24. tomie czasopisma „Acta Universitatis Lodziensis. Kształcenie Polonistyczne Cudzoziemców” zatytułowanego Odmiany stylistyczne i specjalistyczne języka, ksztatcenie dzieci i młodzieży. Autorzy omawianych tekstów koncentrują się na takich kwestiach jak: nauczanie stylów funkcjonalnych polszczyzny, kształcenie biznesowe i zawodowe, miejsce polszczyzny potocznej w nauczaniu języka polskiego jako obcego, specyfika nauczania języka polskiego dzieci i młodzieży, metody i praktyki stosowane podczas lekcji języka obcego, użyteczność podręczników i materiałów dydaktycznych, programy nauczania, zależność między systemem kształcenia a procesem migracyjnym.

Tom 24. Kształcenia Polonistycznego Cudzoziemców zatytułowany Odmiany stylistyczne i specjalistyczne języka, kształcenie dzieci i młodzieży stanowi kontynuację zainicjowanej w tomie 23. czasopisma dyskusji na temat zagadnień nauczania obcokrajowców specjalistycznych odmian języka polskiego ${ }^{1}$. Podjęte roz-

*magda_karasek@wp.pl; Zakład Lingwistyki Stosowanej i Kulturowej, Instytut Filologii Polskiej i Logopedii, Wydział Filologiczny, 90-236 Łódź, ul. Pomorska 171/173.

${ }^{1}$ Artykuły prezentowane w pierwszych trzech częściach niniejszego tomu są owocem rozważań i dyskusji naukowych prowadzonych podczas konferencji Odmiany specjalistyczne i stylistyczne w nauczaniu języków obcych i języka polskiego jako obcego/drugiego zorganizowanej przez Katedrę Lingwistyki Stosowanej i Kulturowej Uniwersytetu Łódzkiego w dniach 13-14 maja 2016 r. 
ważania skupiają się teraz wokół trzech zasadniczych obszarów: nauczania stylów funkcjonalnych polszczyzny (przede wszystkim, choć nie tylko) ze szczególnym uwzględnieniem stylu naukowego, urzędowo-kancelaryjnego i potocznego, akademickiej odmiany języka polskiego, kształcenia biznesowego i zawodowego oraz problematyki nauczania języka polskiego jako obcego dzieci i młodzieży. Zawartość tomu dowodzi tego, że glottodydaktyka polonistyczna, podobnie jak nauczanie innych języków, specjalizuje się - otwierając się na kształcenie określonych grup uczących się, a badacze uważnie obserwują te nowe zjawiska edukacyjne.

Część pierwszą tomu otwiera artykuł Edyty Pałuszyńskiej pt. Charakterystyka stylu naukowego i terminów na tle wariantywności języka w kraju i za granica. Autorka, zwracając uwagę na fakt, że język polski nie jest tworem homogenicznym lecz funkcjonuje jako zbiór licznych odmian, prowadzi wywód na temat wyznaczników stylu naukowego oraz cech terminu - najważniejszego leksykalnego kwalifikatora stylu naukowego. E. Pałuszyńska zauważyła, że termin jest tym, co nazywa pojęcie, nie, jak to jest w przypadku jednostki leksykalnej należącej do języka ogólnego, pojęcie oznacza. Mimo ograniczonej sfery występowania i użycia terminów specjalistycznych nie można zapominać o nich w procesie nauczania języka polskiego jako obcego, często ograniczonego do ogólnej odmiany polszczyzny. Język potoczny i ogólny, choć stanowią punkt wyjścia dla pozostałych odmian (środowiskowych i profesjonalnych), nie są w stanie przejąć funkcji właściwych dla języka specjalistycznego. „Naukowych twierdzeń i wiedzy nie da się przekazać bez terminów specjalistycznych. $Z$ tego powodu są one nieprzekładalne na język potoczny bez utraty istotnych treści, a nawet przekłamań" przekonuje E. Pałuszyńska.

Nauczanie odmian specjalistycznych jest odpowiedzią na potrzeby uczących się, którzy, nabywając umiejętności socjolingwistyczne, stają się kompetentnymi uczestnikami komunikacji prywatnej, publicznej, edukacyjnej i zawodowej. Nauczanie różnego rodzaju odmian specjalistycznych stanowi wyzwanie dla glottodydaktyki polonistycznej. Pamiętanie w procesie kształcenia o złożoności polszczyzny jest istotne także dla uczących się należących do polskiej polonii. Język zbiorowości polonijnych często zredukowany jest bowiem do jednego wariantu polszczyzny, niejednokrotnie wykazuje cechy kodu ograniczonego. Kompetencja komunikacyjna to dziś także znajomość odmian specjalistycznych języka polskiego. Zwraca na to uwagę także Maria Czempka-Wewióra, która opisuje sposoby przybliżania cudzoziemcom stylu naukowego i urzędowo-kancelaryjnego na dwusemestralnym kursie prowadzonym w Szkole Języka i Kultury Polskiej Uniwersytetu Śląskiego przygotowującym obcokrajowców do podjęcia studiów w Polsce. Autorka omawia m. in. stosowane podczas kursu przygotowawczego ćwiczenia obejmujące poszczególne sprawności językowe. Opanowanie oficjalnych odmian polszczyzny ma ułatwić studentom funkcjonowanie w życiu akademickim - czynne uczestniczenie w działaniach naukowych (udział w wy- 
kładach, seminariach, dyskusjach, konsultacjach, rozumienie i przetwarzanie tekstów naukowych, przygotowywanie prac zaliczeniowych) oraz radzenie sobie w sytuacjach administracyjno-prawnych (komunikacja w urzędach, bibliotekach). Zarówno styl naukowy, jak i urzędowo-kancelaryjny wymaga od słuchaczy opanowania określonej leksyki, struktur gramatycznych i składniowych, a także form gatunkowych, takich jak: artykuł, referat, bibliografia, dyskusja, e-mail, list motywacyjny, umowa, reklamacje, odwołania.

Refleksji na temat uzupełnienia programów nauczania o słownictwo specjalistyczne z zakresu prawa i administracji podjęła się Samanta Busiło. Autorka przeanalizowała Ramowy program kursów nauki języka polskiego dla cudzoziemców opracowany przez Ministerstwo Edukacji Narodowej oraz Programy nauczania języka polskiego jako obcego. Poziomy A1-C2 pod kątem ich przydatności w przygotowywaniu treści programowych dla cudzoziemców imigrantów i uchodźców - uczestników szkoleń języka polskiego jako obcego. Badaczka przedstawia autorską propozycję rozszerzenia i uszczegółowienia takich obszarów, jak: terminy z zakresu języka prawa i administracji oraz słownictwa typowego dla stylu urzędowo-kancelaryjnego, role komunikacyjne oraz zadania językowe wymagające znajomości elementów języka prawa i administracji, teksty użytkowe z poszczególnych poziomów językowych. Sugerowane zmiany i uzupełnienia mają stanowić wsparcie w kształceniu kompetencji komunikacyjnej cudzoziemca-imigranta na co dzień obcującego $z$ tekstami i słownictwem z kręgów języków specjalistycznych w kontaktach z polskimi urzędnikami czy pracownikami placówek edukacyjnych.

Kolejne 4 teksty w pierwszej części 24. tomu „Kształcenia Polonistycznego Cudzoziemców" stanowią rozważania nad stylem potocznym w procesie nauczania języka polskiego jako obcego. Konrad Szamryk, opierając się na precyzyjnych wyliczeniach statystycznych, dokonuje opisu oraz omawia funkcje leksyki potocznej obecnej w podręczniku Polski, krok po kroku. Poziom A1. Analizy autora prowadzą do konkluzji, zgodnie z którą potoczność w badanych tekstach i ćwiczeniach ma wartość przede wszystkim stylizacji stosowanej w funkcji urozmaicenia treści. Przeprowadzone przez K. Szamryka obliczenia częstości użycia wyrazów dowodzą, że leksyka potoczna nie może sama w sobie stanowić przedmiotu nauczania. Przedstawione parametry dotyczące potocyzmów w omawianym skrypcie nie służą utrwalaniu i zapamiętywaniu materiału. Proces ten utrudnia także struktura części mowy wyrazów potocznych w której przeważają wykrzykniki.

Elementom potocznym obecnym w podręcznikach do nauczania języka polskiego jako obcego przygląda się także Rafał Maćkowiak. Analizując trzy opracowania: Hurra!!! Po polsku 1, Polski, krok po kroku 1 i Polski jest cool, sprawdza, czy zawarte w nich konstrukcje pytające odpowiadają tym, które rejestruje powszechny zwyczaj językowy. Treści w podręcznikach zestawione są z wynikami ankiety przeprowadzonej wśród młodych rodzimych użytkowników języka 
polskiego, którzy oceniali struktury pod względem ich aktualności i naturalności oraz zgłaszali własne propozycje konstrukcji, których używają w codziennych rozmowach. Wnioski, które wyciąga autor to jednocześnie cenne wskazówki dla nauczycieli. Język podręczników nie nadąża bowiem za dynamicznymi zmianami w uzusie. Ciągłe przeobrażenia potocznej odmiany polszczyzny sprawiają, że - jak zauważa R. Maćkowiak - niektóre zawarte w podręcznikach teksty wydają się nienaturalne, nie odpowiadają powszechnie używanym zwrotom i wyrażeniom.

O statusie polszczyzny potocznej w glottodydaktyce pisze także Justyna Sochacka. Punktem wyjścia w rozważaniach badaczki stała się ankieta sprawdzająca wiedzę na temat potocznej odmiany języka polskiego, w tym znajomości wyrażeń potocznych, przeprowadzona wśród cudzoziemców - uczestników zajęć z języka polskiego na poziomie podstawowym. Wyniki ankiety, a także prośby samych uczących się przekonały lektorkę, że zagadnienie jest dla obcokrajowców interesujące, a jego podejmowanie na lekcjach potrzebne i celowe. Drugą część artykułu stanowi opis lekcji poświęconej nauczaniu elementów stylu potocznego. Obserwacje prowadzone podczas zajęć potwierdziły tezę o zasadności nauczania języka potocznego już na najniższych poziomach zaawansowania językowego.

Anna Rabczuk zwraca uwagę na jedną z odmian języka potocznego - gwarę młodzieżową, która, jak przekonuje, rzadko pojawia się w programach kursów języka polskiego jako obcego. Poznanie slangu jest istotne przede wszystkim z punktu widzenia młodych obcokrajowców, którzy chcą odkrywać polszczyznę taką, jaką na co dzień posługują się ich polscy rówieśnicy. Umiejętność identyfikacji i posługiwania się wyrażeniami slangowymi przez cudzoziemców pozwala zatrzeć granicę między rodzimymi użytkownikami języka polskiego a tymi, którzy polszczyznę dopiero poznają. Wspólny kod umożliwia więc kulturowe zbliżenie, zapobiega etykietkowaniu. Trudność nauczania slangu wynika głównie z jego nietrwałości (wiele z leksemów slangowych pozostaje okazjonalizmami), dynamiczności i silnego uzależnienia od czynników sytuacyjnych, takich jak wiedza o relacjach między uczestnikami sytuacji komunikacyjnej. A. Rabczuk podaje przykłady ćwiczeń, które mogą być pomocne w nauczaniu gwary młodzieżowej. Badaczka podkreśla jednak, że elementy slangowe, charakterystyczne dla stosunkowo niewielkiego grona użytkowników polszczyzny, nie powinny stanowić pierwszego etapu w nauczania języka polskiego jako obcego.

Część pierwszą tomu zamyka komparatystyczny artykuł Radosława Kalety dotyczący różnic stylistycznych pomiędzy polskimi i białoruskimi leksemami. Autor zestawia słownikowe przykłady wyrazów, które w języku białoruskim są neutralne, w polszczyźnie zaś mają wyraźne nacechowanie stylistyczne. Różnice rejestrów stają się przyczyną błędów popełnianych przez Białorusinów uczących się języka polskiego. R. Kaleta zauważa potrzebę przygotowania odpowiedniego opracowania słownikowego będącego pomocą zarówno dla uczniów, jak i lektorów języka polskiego. 
Wprowadzeniem do drugiej część tomu jest artykuł Grażyny Zarzyckiej Język polski w odmianie akademickiej. Propozycja programu kursu adresowanego do studentów zagranicznych przygotowujacych się do studiów wyższych w Polsce. Badaczka wnikliwie porównuje angielskie i polskie koncepcje glottodydaktyczne poświęcone metodom przygotowywania zagranicznych studentów do studiów wyższych w Polsce. G. Zarzycka podkreśla specyfikę języka polskiego w odmianie akademickiej, zwracając uwagę, że jest to polszczyzna, za pomocą której studenci podejmują różnorodne działania komunikacyjne związane ze studiowaniem w Polsce. Niezależnie od wybranego kierunku studiów program kursu musi koncentrować się na wykształceniu kompetencji umożliwiających słuchaczom pełne uczestniczenie w sytuacjach komunikacyjnych charakterystycznych dla środowiska akademickiego. Obok przygotowania językowego oraz poznania niezbędnej leksyki umożliwiającej sprawną analizę tekstów naukowych, program powinien uwzględniać także kształcenie socjokulturowe oraz umożliwić uczącym się zdobycie lub uaktywnienie umiejętności studiowania. W artykule znajdujemy autorską koncepcję programową uwzględniającą wszystkie te postulaty.

Anna Seretny koncentruje swoje dociekania na temat kształcenia specjalistycznego na zagadnieniu nauczania leksyki - na tej warstwie, w której różnice pomiędzy językiem ogólnym a językami specjalistycznymi są najbardziej widoczne. Badaczka wskazuje na konieczność przemyślanej ekscerpcji i uporządkowania materiału słownikowego na potrzeby glottodydaktyki specjalistycznej oraz dostosowanie go do profilu uczących się. Inne bowiem są oczekiwania tych, którzy dopiero zamierzają uczyć się zawodu, inne zawodowo czynnych profesjonalistów. Rozróżnienie to prowadzi do wydzielenia dwóch rodzajów kształcenia: dydaktyki języka specjalistycznego na potrzeby akademickie oraz nauczania języka specjalistycznego dla celów zawodowych. Celem każdego z wariantów nauczania pozostaje osiągnięcie przez uczących się zawodowej kompetencji komunikacyjnej.

Tematem rozważań Ewy Komorowskiej jest sylwetka uczącego się. Autorka analizuje profil studenta-biznesmena i specyfikę nauczania języka polskiego w kontekście biznesowym. Na podstawie przeprowadzonego przez siebie badania E. Komorowska kreśli charakterystykę uczących się ze względu na ich potrzeby, problemy, motywacje i role przyjmowane w procesie nauczania. $\mathrm{Z}$ obserwacji badaczki wynika m.in., że opisywani cudzoziemcy są niezwykle autonomiczni, silnie zmotywowani, świadomi swoich potrzeb, mają jasno sprecyzowany cel uczenia się, oczekują szybkich rezultatów kształcenia, chcą współdecydować o tym, czego będą nauczani. Niejednorodność studentów biznesowych wymusza na nauczycielu wykonanie szczegółowej analizy potrzeb uczniów, weryfikowanej na kolejnych etapach kursu.

Języki specjalistyczne to także wyzwanie dla wykładowców kształcących przyszłych nauczycieli i tłumaczy. Trudności związane z thumaczeniem doku- 
mentacji i korespondencji firmowej z języka polskiego na bułgarski i z bułgarskiego na polski omawia Steliana Aleksandrova. Autorka wskazuje na rozbieżności w procesie przygotowywania do zawodu thumacza na studiach w Bułgarii i w Polsce, które wynikają miedzy innymi z różnic pomiędzy systemami gramatycznymi języka bułgarskiego i polskiego. Zajęcia mają na celu zapoznanie słuchaczy ze strategiami i technikami tłumaczeniowymi oraz poszerzenie zasobu leksykalnego studentów. W przypadku polsko-bułgarskich i bułgarsko-polskich thumaczeń dokumentacji firmowej proces nauczania powinien, zdaniem autorki artykułu, uwzględnić interferencje, które wyjątkowo często stają się przyczyną błędów w przekładach.

Oryginalny temat rozważań proponuje Anna Borowska. W swoim artykule badaczka przybliża odbiorcy strukturę międzynarodowej komunikacji lotniczej, która odbywa się za pomocą specjalistycznego angielskiego języka lotniczego. Nauczaniem tej odmiany języka zajmują się wyłącznie wyspecjalizowani instruktorzy, znający specyfikę zawodu i posiadający doświadczenie operacyjne. Są to między innymi piloci i kontrolerzy ruchu, którzy sami są poddawani egzaminom sprawdzającym znajomość uproszczonego języka angielskiego i angielskiej frazeologii lotniczej. A. Borowska charakteryzuje również tzw. aviation standard phraseology, zwracając uwagę na specyfikę i uwarunkowania funkcjonowania tej nazwy w języku polskim.

Zmaganiom dydaktyków języka poświęca swój tekst Katarzyna Bednarska, która prowadzi na Uniwersytecie Łódzkim ćwiczenia lektoratowe z języka słoweńskiego ze studentami studiów lingwistyczno-biznesowych. W ramach zajęć słuchacze uczą się języka specjalistycznego finansów, logistyki i informatyki. $\mathrm{K}$. Bednarska prezentuje sposoby nauczania i opisuje wykorzystywane na lekcjach materiały dydaktyczne, które, z powodu braku odpowiednich gotowych podręczników, muszą być przygotowywane przez lektora. Autorka wskazuje na przydatne w tworzeniu pomocy dydaktycznych źródła, takie jak: słoweńskie gazety i czasopisma, strony internetowe, podręczniki do szkół zawodowych.

O konieczności współpracy interdyscyplinarnej w przygotowywaniu dydaktycznego tekstu specjalistycznego przekonuje Grzegorz Rudziński. Lingwista i glottodydaktyk, odwołując się do opracowanego wespół z matematykami polskiego podręcznika do nauczania cudzoziemców matematyki, wymienia problemy, jakie towarzyszą tworzeniu materiałów dydaktycznych oraz kształceniu matematyki obcokrajowców w środowisku polskim. Opisywane trudności wynikają z faktu, że język polski staje się zarówno narzędziem, jak i przedmiotem nauczania. Istotne są także uwarunkowania lingwakulturowe, które są czynnikami determinującymi identyfikowanie pojęć i terminów. Dobry podręcznik musi z jednej strony być narzędziem do nauczania matematyki, z drugiej winien brać pod uwagę uwarunkowania językowe wpływające na stopień trudności omawianych zagadnień. 
O trudnej umiejętności czytania tekstów specjalistycznych pisze Urszula Swoboda-Rydz w anglojęzycznym artykule pt. Move beyond the text. Czytanie tekstów specjalistycznych wiąże się z koniecznością skonfrontowania treści lektury z wiedzą i doświadczeniem czytelnika. Tylko wtedy spotkanie odbiorcy z tekstem będzie krytyczne. Autorka udowadnia powyższą tezę, analizując przebieg warsztatów przeprowadzonych w maju 2016 r. podczas łódzkiej konferencji poświęconej odmianom specjalistycznym i stylistycznym w nauczaniu języków obcych i języka polskiego jako obcego/drugiego. Wnioski z przeprowadzonego eksperymentu stanowią jednocześnie wskazówki dydaktyczne dla nauczycieli pracujących z tekstami specjalistycznymi podczas zajęć.

Trzecia część niniejszego tomu poświęcona jest nauczaniu języka polskiego jako obcego dzieci i młodzieży. Pierwszy artykuł w tej sekcji tematycznej stanowi omówienie technik pracy z uczniem z barierą językową na zajęciach przedmiotowych w szkole polskiej. Podjęty przez badaczkę temat jest odpowiedzią na przeobrażenia w polityce Unii Europejskiej dotyczącej systemów szkolenia i kształcenia w związku z dynamiką procesów migracyjnych. U. Majcher-Legawiec dokładnie opisuje regulacje prawne dotyczące edukacji obywateli polskich i niepolskich w polskiej szkole, w kontekście których omawia takie zagadnienia jak: zadania szkoły wielokulturowej, indywidualizacja procesu nauczania, diagnoza pedagogiczna, praca z uczniem z doświadczeniem migracyjnym.

Opanowaniu języka przez dzieci imigranckie i rozwojowi dzieci dwujęzycznych poświęca swój artykuł także Agnieszka Rabiej. Autorka omawia ideę zintegrowanego nauczania językowo-przedmiotowego oraz podejście polegające na nauce języka poprzez treść, którego podstawowym założeniem jest rozwijanie umiejętności czytania. A. Rabiej podkreśla, że sprawne posługiwanie się edukacyjną odmianą języka, w opanowaniu której decydujące znaczenie ma biegłość w zakresie operowania tekstem, wspomaga rozwój kompetencji akademickich, a w rezultacie zapewnia sukces edukacyjny. Czytanie łączy wiedzę przedmiotową i językową, przyczyniając się do poznawania przez dziecko różnorodnych, także specjalistycznych, odmian języka.

W sekcji tomu zawierającej recenzje omówionych zostało pięć opracowań glottodydaktycznych. Wysoko oceniona przez Grażynę Zarzycką seria podręczników do nauki specjalistycznego języka polskiego jako obcego pod red. Urszuli Sajkowskiej Edukacja - Praca - Integracja przeznaczona jest dla cudzoziemców, którzy chcą podjąć pracę w Polsce. Recenzentka podkreśla pragmatyczny charakter publikacji, wykorzystanie bogatego materiału ikonograficznego oraz różnorodnych tekstów autentycznych.

Iwona Janowska dokonuje charakterystyki międzykulturowego podręcznika autorstwa Tamary Czerkies Bliżej tekstów adresowanego do studentów koreańskich uczących się języka polskiego na poziomach B1+-B2+. Recenzentka podkreśla wartość tej pomocy dydaktycznej, zwracając uwagę na właściwy dobór 
autentycznych materiałów literackich i konstrukcję zadań rozwijających kompetencję językową i kulturową uczniów.

Ostatnia recenzja stanowi prezentację książki Michaliny Biernackiej Znajdź z polskim wspólny język adresowaną do nauczycieli języka polskiego jako obcego/ drugiego oraz studentów specjalizacji lub studiów glottodydaktycznych. W opracowaniu szczegółowo omówiono wiele zagadnień dotyczących fonodydaktyki języka polskiego jako obcego. Recenzentka Beata Grochala zwraca uwagę, że pracę tę powinien przeczytać każdy, kto zajmuje się nauczaniem języka polskiego jako obcego.

Tom zamyka Sprawozdanie z przebiegu państwowych egzaminów certyfikatowych z języka polskiego jako obcego organizowanych na Wydziale Filologicznym Uniwersytetu Łódzkiego sporządzone przez Iwonę Dembowską-Wosik. Autorka pełniła funkcję przewodniczącej komisji egzaminacyjnej podczas pierwszego egzaminu we wrześniu 2016 r. Wydział Filologiczny Uniwersytetu Łódzkiego był jedną z pierwszych instytucji, które uzyskały uprawnienia do organizacji egzaminów na nowych zasadach wynikających ze znowelizowanej Ustawy o języku polskim z 12 czerwca 2015 roku. Wykwalifikowana kadra specjalistów w zakresie filologii polskiej i glottodydaktyki może przeprowadzać egzaminy na wszystkich poziomach zaawansowania językowego w obu grupach - zarówno dla osób dorosłych jak i dla dzieci i młodzieży. W pierwszej sesji wzięło udział 68 cudzoziemców, którzy zdawali egzaminy na 3 poziomach zaawansowania: progowym (B1), średnim ogólnym (B2) oraz efektywnej biegłości użytkowej (C1) w grupie dostosowanej do potrzeb osób dorosłych.

\section{Magdalena Karasek}

\section{NEW DIMENSIONS OF GLOTTODIDACTICS: THE PROBLEMS OF TEACHING STYLISTIC AND SPECIALIZED VARIANTS OF POLISH AND OTHER LANGUAGES AND EDUCATION OF CHILDREN AND ADOLOSCENTS}

Keywords: didactics, specialist variants, research, style, genres, teaching Polish as a foreign and second language

Summary. The article presents the main theses and concepts of the texts published in the 24th volume of the journal "Acta Universitatis Lodziensis. Kształcenie Polonistyczne Cudzoziemców ("Studies in the Teaching of Polish to Foreigners") entitled Stylistic and Specialized Variants of Language, Education of Children and Adolescents. The authors of the discussed texts focus on issues such as teaching functional styles of Polish, business and professional education, the place of colloquial Polish in teaching Polish as a foreign language, the specific character of teaching the Polish language to children and young people, methods and practices used in foreign language lessons, usefulness of textbooks and teaching materials, curricula, the relationship between educational system and migration process. 